\title{
Successful treatment with pineapple juice of a gastric bezoar caused by mastic
}

A 59-year-old man was admitted to our department with epigastric pain and nausea. The patient mentioned that he had swallowed heated mastic to treat constipation shortly before his symptoms developed. He had no history of any diseases. His vital signs were within normal limits. The physical examination findings were normal, and the results of laboratory tests were unremarkable.

Upper gastrointestinal endoscopy revealed a gastric bezoar 6 to $7 \mathrm{~cm}$ in diameter ( Fig.1). Although there is uncertainty concerning the volume of pineapple juice, we recommended that our patient drink $1 \mathrm{~L}$ of fresh pineapple juice 3 times a day (once after each meal) for the next 2 weeks. The patient again underwent upper gastrointestinal endoscopy after the ingestion of fresh pineapple juice. We found that the gastric bezoar had dissolved completely ( $\bullet$ Fig.2), so that surgery could be avoided.

Gastric bezoars are unusual. They are frequently associated with peptic ulcer, diabetes mellitus, or gastric surgery. In the medical literature, many invasive and noninvasive methods to dissolve gastric bezoars, such as mechanical fragmentation and medical treatment, have been described $[1,2]$. The consumption of pineapple juice as a noninvasive method to dissolve bezoars has also been reported [3]. The putative mechanism of dissolution is that pineapple juice is rich in bro- melain, a proteolytic enzyme. We are the first to report the administration of pineapple juice to dissolve a gastric bezoar caused by swallowing heated mastic.

Endoscopy_UCTN_Code_TTT_1AO_2AL

Competing interests: None

\section{Barış Yılmaz, Akif Altınbas, Fuat Ekiz, Bora Aktaş}

Diskapi Yildirim Beyazit Education and Research Hospital, Gastroenterology, Ankara, Turkey

\section{References}

1 Bounds BS. Endoscopic retrieval devices. Tech Gastrointest Endosc 2006; 8: 16-21

2 Martinez de Juan F, Martinez-Lapiedra C, Picazo V. Phytobezoar dissolution with Coca-Cola. Gastroenterol Hepatol 2006; 29 : 291-293

3 Simsek Z, Altinbas A, Yuksel I et al. Effective treatment with pineapple juice in small bowel obstruction due to phytobezoar in a gastrectomized patient. Dig Endosc 2011; 23: 197

\section{Bibliography}

Dol http://dx.doi.org/

10.1055/s-0034-1377598

Endoscopy 2014; 46: E519

(c) Georg Thieme Verlag KC

Stuttgart · New York

ISSN 0013-726X

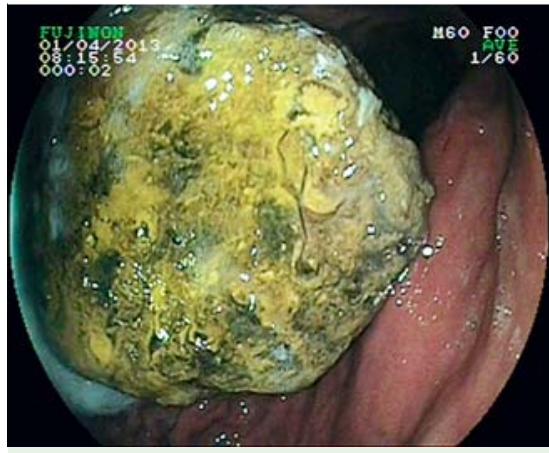

Fig. 1 Endoscopic image of a gastric bezoar before the ingestion of pineapple juice.

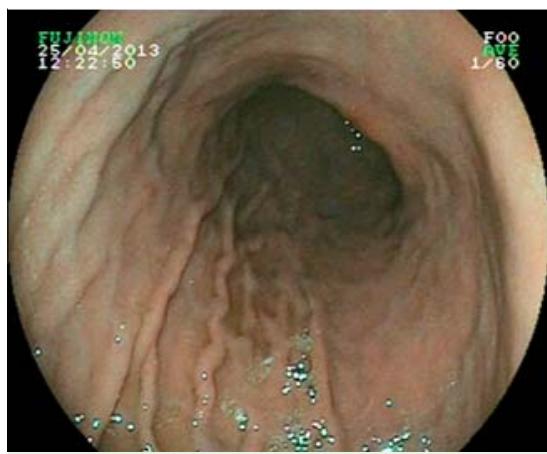

Fig. 2 The bezoar has dissolved after the ingestion of pineapple juice.

Corresponding author

Barıș Yılmaz, MD

Camlikevler mahallesi, 4. Blok No: 6 Toprakkale

Osmaniye, Turkey

Fax: +90-328-8257072

dryilmazb@gmail.com 